\title{
Utilization of Uncaria gambir Roxb filtrate in the formation of bioactive edible films based on corn starch
}

\author{
Budi SANTOSO ${ }^{1 \star}$, Ranti HAZIRAH ${ }^{1}$, Gatot PRIYANTO ${ }^{1}$, dan HERMANTO ${ }^{1}$, dan SUGITO$^{1}$
}

\begin{abstract}
The objective of this research was to determine the effect of Uncaria gambir Roxb filtrate addition on functional edible films based on corn starch. This study used a Factorial Randomized Completely Design with two treatments and three replication for each treatment. The first factor was the concentration of Uncaria gambir Roxb filtrate $(20 \%, 30 \%, 40 \%)$ and the second factor was the mixing separation method (filtering, centrifuge $1000 \mathrm{rpm}$, centrifuge $2000 \mathrm{rpm}$ ). The results showed that treatment of Uncaria gambir Roxb filtrate and the mixing separation method had significant effect on thickness, elongation percentage, water vapour transmission rate, antioxidant and antibacterial activities of edible film. The interaction of Uncaria gambir Roxb filtrate and the mixing separation method had significant effect on water vapour transmission rate. The best treatment based on edible film characteristics was $40 \%$ concentration of Uncaria gambir Roxb filtrate and the mixed separation method of $1000 \mathrm{rpm}$ centrifugation.
\end{abstract}

Keywords: corn starch; edible film; filtrate; Uncaria gambir Roxby.

Practical Application: Edible films applied on food products that play an important role on their conservation, distribution and marketing.

\section{Introduction}

Bioactive edible film is thin layer made from biopolymer constituents such as starch, protein and lipid that has function as food product packaging and contains natural functional compound. Researches on bioactive edible film had continously increasing, especially in term of natural functional compound used for its processing. Maizura et al. (2007) had described that the use of lemongrass at concentration of 0.1 to $0.4 \%$ in edible film formula based on modified cassava starch had produced edible film that capable to inhibit the growth of Escherichia coli O157:H7 bacteria. Pranoto et al. (2005) had stated that incorporation of garlic oil with magnitude of $0.4 \%(\mathrm{v} / \mathrm{v})$ in formula of alginate-based edible film can inhibit bacteria of Staphylococcus aureus and Bacillus cereus. Edible film with formulation of 3\% corn starch concentration and 7\% Curcuma aeruginosa Roxb squeeze concentration contains total phenol of $555.16 \mu \mathrm{g} / \mathrm{g}$ and antioxidant activity of $52.10 \%$ (Kusumawati \& Putri, 2013). The addition of $150 \mathrm{mg}$ catechin compound on Gelidium corneum (GC)-based edible film can inhibit microbia growth of Eschericha coli with magnitude of $1.93 \mathrm{log}$ CFU/g and Listeria monocytogenes with magnitude of $1.44 \log \mathrm{CFU} / \mathrm{g}$ on sausage (Ku et al., 2008).

According to Taniguchi et al. (2007), gambier leaves extract contains catechins compound in the range of 28 to $54 \%$. Pambayun et al. (2007) had described that catechins compound in gambier leaves extract had antibacterial characteristic especially for Gram-positive bacteria. Santoso et al. (2016) had reported that ganyong starch-based edible film containing $3 \%(\mathrm{w} / \mathrm{v})$ gambier powder could inhibit the growth of Staphylococcus aureus bacteria with inhibition power diameter (IPD) of $8.2 \mathrm{~mm}$. The IPD value from this research was still low and can be elevated by increasing gambier powder quantity in edible film formulation. However, gambier powder addition higher than 3\% (w/v) had produced negative impact on edible film. Edible film had dark brown color, became thicker and had low elasticity due to this negative impact which in turn it could not fulfill the stated standard. The use of gambier powder is replaced with gambier powder filtrate in order to overcome the above negative impact.

Gambier filtrate is produced by dissolving gambier powder in water followed by stirring and mixture separation into liquid (filtrate) and gambier oilcake. Separation process for gambier filtrate is done through filtration and centrifugation. Filtration is a separation method to separate solid zat from liquid by using porous equipment based on particle size differences. Centrifugation is used as substitute to filtration if solid particles are very fine and mixture volume is less. The use of gambier filtrate with high concentration of catechins compound and low solid content in edible film formulation have positive impact in increasing antibacterial and antioxidant characteristics as well as have no negative impact to physical and chemical characteristics of edible film.

\section{Material and methods}

Equipments used in this study were hot plate, magnetic stirrer, vortex, oven, desicator, Haze meter serie NDH-200 of Nipon Denshoku Kogyo Co Ltd, micrometer (Roch) 
(A281500504, Sisaku SHO Ltd, Japan), Testing Machine MPY (Type: PA-104-30, Ltd Tokyo, Japan), and water vapor transmission rate tester Bergerlahr.

Materials used in this research were as follows: clean water, aquadest, ingredients for analysis, gambier (Uncaria gambir Roxb) obtained from Km 5 Market of Palembang, 5) glycerol, 6) HPMC (Hydroxy propyl methyl cellulose), 7) bacterial culture of Stapylococcus aereus, 8) nutrient agar (NA) and 9) corn starch.

\subsection{Processing of gambier powder filtrate}

Dry gambier powder is crushed until fine using mortar and subsequently is sieved using 80 mesh siever. Weighing of fine gambier powder according to treatments $(20 \%, 30 \%$ and $40 \%(\mathrm{w} / \mathrm{v}))$ and then put it into volumetric glass and added with aquadest until $100 \mathrm{~mL}$ boundary mark. The suspension is stirred by using magnetic stirrer for 10 minutes and sieving was done according to the method of treatments (sieve paper, centrifugation at $1000 \mathrm{rpm}$ and centrifugation at $2000 \mathrm{rpm}$ ) and followed by filtrate collection.

\subsection{Edible film processing (Modified from Harmely et al., 2014)}

Corn stach with magnitude of $6 \%(\mathrm{w} / \mathrm{v})$ is added with $100 \mathrm{~mL}$ aquadest and followed by stirring operation. Starch suspension is heated at temperature of about $60{ }^{\circ} \mathrm{C}$ while stirring until complete gelatinization is occurred. HPMC with magnitude of $1.6 \mathrm{~g}$ is put into $80 \mathrm{~mL}$ hot water and mixed into $100 \mathrm{~mL}$ starch suspension. Glycerol with magnitude of $3 \%(\mathrm{v} / \mathrm{v})$ is added while stirring at temperature of about $60{ }^{\circ} \mathrm{C}$ followed by gambier filtrate addition with magnitude of $5 \%$ (v/v.final) according to treatments and subsequently is stirred until homogenous. Suspension is poured and leveled into the mould followed by drying in oven at temperature of 45 to $50^{\circ} \mathrm{C}$ for 24 hours. After drying operation, edible film is put into dessicator for 6 hours. Finally, edible film is released from the mould and it is ready for analysis.

\subsection{Experimental design and statistical analysis}

This research used Factorial Randomized Completely Design with two treatment factors consisting of filtrate with gambier powder concentration $(A): A_{1}=20 \%, A_{2}=30 \%$ and $\mathrm{A}_{3}=40 \%(\mathrm{w} / \mathrm{v})$ and mixed separation method $(\mathrm{B}): \mathrm{B}_{1}=$ sieve paper, $B_{2}=$ centrifugation at $1000 \mathrm{rpm}$ and $\mathrm{B}_{3}=$ centrifugation at $2000 \mathrm{rpm}$. The observed parameters were consisted of physical analysis: edible film thickness (American Society for Testing and
Materials, 1997), elongation percentage of edible film (American Society for Testing and Materials, 1997), compressive strength (American Society for Testing and Materials, 1997), water vapour transmission rate (American Society for Testing and Materials, 1997). Chemical analysis: water content (American Society for Testing and Materials, 1997) and total phenol content (Chaovanalikit \& Wrolstad, 2004) and functional analysis: antioxidant (DPPH method) and antibacterial (Hamilton-Miller \& Shah, 2000). Data will be processed by using analysis of variance (Anova). Treatments having significant effect will be further analyzed by using Honestly Significant Different (HSD) test at 5\% level.

\section{Results and discussion}

\subsection{Thickness}

Average thickness of the produced edible film was in the range of $0.097 \mathrm{~mm}$ to $0.143 \mathrm{~mm}$ and had fulfilled the standard of JIS 1975 which stated that maximum thickness for edible film is $0.25 \mathrm{~mm}$. The highest thickness value of edible film was found on $A_{3} B_{2}$ treatment, whereas the lowest one was found on $A_{1} B_{1}$ treatment. Average value of edible film thickness was shown in Figure 1.

Analysis of variance results showed that treatments of gambier filtrate and mixed separation method had significant effect on edible film thickness, whereas treatment interaction had no significant effect on edible film thickness. Results of HSD test for treatments of gambier powder filtrate and mixed separation method were shown in Table 1 and Table, respectively.

Results of HSD test (Table 1) showed that higher addition of gambier powder filtrate results in thicker edible film. This is due to the fact that gambier powder filtrate contain catechins

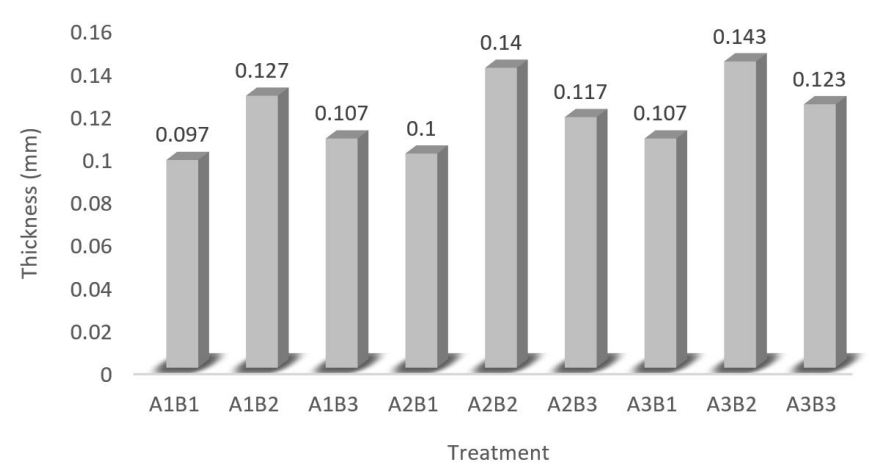

Figure 1. Average thickness of edible film (mm).

Table 1. HSD test for gambier powder filtrate in term of thickness, elongation percentage, water vapour transmission rate, $\mathrm{IC}_{50}$ and inhibition power diameter (IPD) of the produced edible film.

\begin{tabular}{|c|c|c|c|c|c|}
\hline $\begin{array}{l}\text { Gambier powder } \\
\text { filtrate }(\%)\end{array}$ & $\begin{array}{l}\text { Thickness } \\
(\mathrm{mm})\end{array}$ & $\begin{array}{c}\text { Elongation percentage } \\
(\%)\end{array}$ & $\begin{array}{c}\text { Water vapour } \\
\text { transmission rate } \\
\left(\mathrm{g} \cdot \mathrm{m}^{-2} \cdot \mathrm{day}^{-1}\right)\end{array}$ & $\begin{array}{c}\mathrm{IC}_{50} \\
(\mathrm{ppm})\end{array}$ & $\begin{array}{l}\mathrm{IPD} \\
(\mathrm{mm})\end{array}$ \\
\hline$A_{1}$ & $0.110+0.015 a$ & $14.78+1.262 \mathrm{a}$ & $20.99+0.705 a$ & $413.25+58.324 a$ & $7.08+1.171 \mathrm{a}$ \\
\hline $\mathrm{A}_{2}$ & $0.119+0.020 b$ & $15.11+1.262 \mathrm{ab}$ & $21.31+0.684 b$ & $368.31+57.475 b$ & $7.25+1.333 \mathrm{ab}$ \\
\hline $\mathrm{A}_{3}$ & $0.124+0.018 b$ & $15.67+1.453 \mathrm{a}$ & $21.62+0.691 c$ & $341.38+72.096 c$ & $7.33+1.526 b$ \\
\hline
\end{tabular}

Remarks: Numbers followed by the same letters at the same columns are not significantly different $(\alpha=0.05)$. 
which is not easily soluble in cold water, but it is only soluble in hot water and develop crystal at dry condition. Crystalic form of catechins compound at dry condition is the dissolved solids in edible film. Higher gambier powder filtrate will cause higher numbers of crystal within film matrix which in turn produce higher concentration of dissolved solids in edible film resulting in increase of edible film thickness. This finding is in accordance to the research that was reported by Santoso (2011) which showed that higher usage of gambier powder results in higher thickness of edible film.

Table 2 showed that edible film thickness with mixed separation method by using sieve paper was lower than mixed separation method by using centrifugation at $1000 \mathrm{rpm}$ or $2000 \mathrm{rpm}$. This is due to the fact that separation using filter paper in principle separate liquid and insoluble solids based on the different of particles size of mixture substance. Thus, only dissolved solids which are available in gambier powder filtrate. Centrifugation separation method is only based on the separated fine particles and not separates dissolved or undissolved solids so that filtrate obtained from centrifugation separation contains dissolved or undissolved solids. Total solid content in filtrate affects the increase of edible film thickness. Park et al. (2004) had described that edible film thickness is affected by total solid available within suspension, solution volume and mould area used for edible film processing.

\subsection{Elongation percentage}

Average value of elongation percentage for edible film was in the range of $13.33 \%$ to $16.67 \%$. Elongation percentage for edible film produced in this research was not fulfill the JIS 1975 standard which requires minimum of $70 \%$ elongation percentage for edible film. This is due to the fact that corn

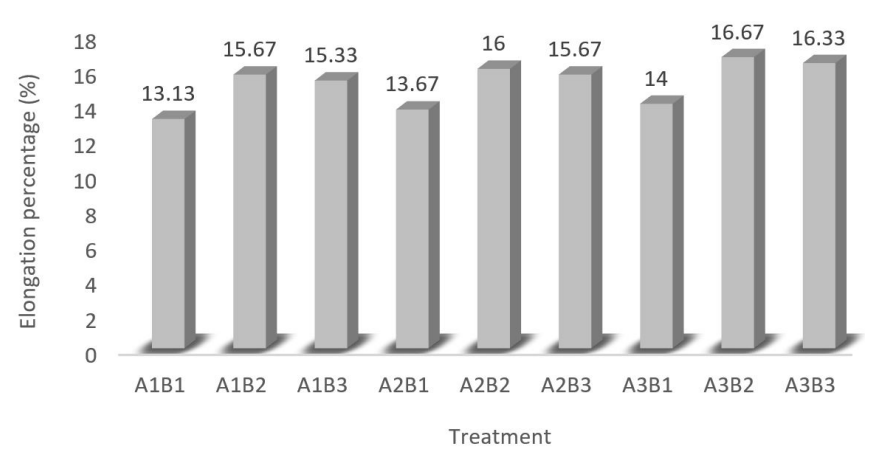

Figure 2. Average value of elongation percentage of edible film. starch used in this research contains high amylose component. The highest elongation percentage for edible film was found on $A_{3} B_{2}$ treatment, whereas the lowest one was found on $A_{1} B_{1}$ treatment. Average value of elongation percentage for edible film was shown in Figure 2.

Analysis of variance results showed that treatments of gambier filtrate and mixed separation method had significant effect on elongation percentage of edible film, whereas interaction of both treatments had no significant effect on elongation percentage of edible film. Results of HSD test for treatments of gambier powder filtrate and mixed separation method toward elongation percentage of edible film were shown in Table 1 and Table, respectively.

Elongation percentage of edible film was increased in accordance to concentration increase of gambier powder filtrate (Table 1) because gambier powder filtrate contains catechins compound which have active group of hydroxyl $(\mathrm{OH})$. The higher the concentration of gambier powder filtrate, the higher the numbers of $\mathrm{OH}$ group which are trapped within edible film matrix. The trapped $\mathrm{OH}$ group can results in cohesive power decrease of edible film matrix which in turn affect the elasticity of edible film. According to Rodriguez et al. (2006), glycerol which contain high numbers of hydroxyl $(\mathrm{OH})$ gugus in matrix system of edible film can increase water vapour transmission rate and elongation percentage of edible film.

HSD test results (Table 2) showed that mixed separation method by using filter paper had lower elongation percentage than that of mixed separation method by using centrifugation. This is related to catechins compound available in gambier filtrate which have semi polar characteristics. Therefore, gambier powder filtrate obtained from mixed separation method by using filtr paper only has dissolved catchins compound, whereas gambier powder filtrate obtained from mixed separation method by using centrifugation method has both dissolved and undissolved catechins compound resulting in higher catechins compound concentration.

\subsection{Water vapour transmission rate}

Average value of water vapour transmission rate for edible film was in the range of 20.2306 to $22.2432 \mathrm{~g} . \mathrm{m}^{-2}$. day ${ }^{-1}$. The highest value of water vapour transmission rate for edible film was found on $A_{3} B_{2}$ treatment, whereas the lowest one was found on $A_{1} B_{1}$ treatment. Average value of water vapour transmission rate for edible film was shown in Figure 3.

Table 2. HSD test for mixed separation method in term of thickness, elongation percentage, water vapour transmission rate, total phenol, $\mathrm{IC}_{50}$ and inhibition power diameter (IPD) of produced edible film.

\begin{tabular}{|c|c|c|c|c|c|}
\hline $\begin{array}{l}\text { Mixed separation } \\
\text { method }\end{array}$ & $\begin{array}{l}\text { Thickness } \\
(\mathrm{mm})\end{array}$ & $\begin{array}{l}\text { Elongation percentage } \\
(\%)\end{array}$ & $\begin{array}{l}\text { Water vapour } \\
\text { transmission rate } \\
\left(\text { g.m }{ }^{-2} \cdot \text { day }^{-1}\right)\end{array}$ & $\begin{array}{l}\mathrm{IC}_{50} \\
(\mathrm{ppm})\end{array}$ & $\begin{array}{l}\text { IPD } \\
(\mathrm{mm})\end{array}$ \\
\hline $\mathrm{B}_{1}$ & $0.101+0.005 a$ & $13.67+0.333 a$ & $20.85+0.805 a$ & $419.16+44.511 \mathrm{a}$ & $6.83+0.192 \mathrm{a}$ \\
\hline $\mathrm{B}_{2}$ & $0.137+0.001 c$ & $16.11+0.509 b$ & $21.92+0.315 c$ & $304.35+47.426 c$ & $7.56+0.509 c$ \\
\hline $\mathrm{B}_{3}$ & $0.116+0.001 b$ & $15.78+0.509 b$ & $21.17+0.294 b$ & $399.43+19.961 b$ & $7.28+0.509 \mathrm{~b}$ \\
\hline
\end{tabular}

Remarks: Numbers followed by the same letters at the same columns are not significantly different $(\alpha=0.05)$. 
Analysis of variance results showed that treatments of gambier powder filtrate concentration and mixed separation method as well as their interaction had significant effect on water vapour transmission rate of edible film. Results of HSD test for treatments of gambier powder filtrate concentration and mixed separation method toward water vapour transmission rate of edible film were shown in Table 1 and Table 2, respectively.

HSD test results (Table 1) showed that higher concentration of gambier powder filtrate results in higher water vapour transmission rate of edible film. This is related to numbers of catechins compound, that is higher concentation of gambier filtrate results in higher numbers of catechins compound within film matrix. Catechins compound containing high numbers of hydroxyl $(\mathrm{OH})$ group causes edible film to have hydrophylic property which in turn affect the increase of water vapour transmission rate of edible film. Sobral et al. (2001) had described that glycerol content in edible film formulation has significant effect on the increase of water vapour transmission rate.

HSD test results (Table 2) showed that water vapour transmission rate of edible film using treatments of mixed separation method with $1000 \mathrm{rpm}$ centrifugation and $2000 \mathrm{rpm}$ centrifugation was significantly different than that of mixed separation method using filter paper. It is estimated that differences in mixed separation method cause differences in catechins content available in edible film. The higher numbers of catechins in edible film will results in higher numbers of hydroxyl $(\mathrm{OH})$ group at edible amongst polymers, increase of free space amongst polymers and increase of polymers mobility. These effects in turn cause the decrease of matrix structural integrity of film and have impact on the increase of water vapour transmission rate of edible film.

Table 3 (HSD) showed that treatments interaction of $20 \%$ gambier filtrate cocentration and mixed separation method using filter paper had produced edible film having the lowest average value of water vapour transmission rate. It is due to the fact that $\mathrm{A}_{1} \mathrm{~B}_{1}$ treatment had the lowest catechins content than other treatments. Low concentration of catechins content within edible film matrix has effect on the decrease of water vapour transmission rate because catechin compound contributes $\mathrm{OH}$ group which affect hydrophilic increase of edible film. According to Nemet et al. (2010), glycerol with its hydroxyl gugus affects the increase of water vapour transmission rate.

\subsection{Antioxidant}

The highest $\mathrm{IC}_{50}$ value of edible film was found on $\mathrm{A}_{1} \mathrm{~B}_{1}$ treatment with magnitude of $258.14 \mathrm{ppm}$, whereas the lowest one was found on $\mathrm{A}_{3} \mathrm{~B}_{2}$ treatment with magnitude of $469.32 \mathrm{ppm}$. The $\mathrm{IC}_{50}$ value is inversely proportional to damping potential of free radical. Low $\mathrm{IC}_{50}$ value found in this research cause higher potential of antioxidant activity, that is edible film concentration required to produce damping activity of free radicals with magnitude of $50 \%$ become smaller (Molyneux, 2004). Average value of $\mathrm{IC}_{50}$ was shown in Figure 4.

Analysis of variance results showed that treatments of gambier powder filtrate concentration and mixed separation method had significant effect on $\mathrm{IC}_{50}$ of edible film, whereas interaction of

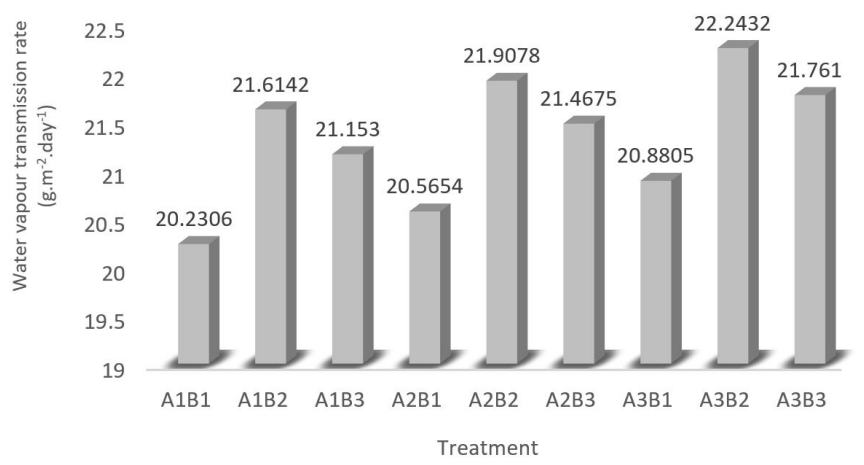

Figure 3. Average value of water vapour transmission rate of edible film.

Table 3. HSD test for the effect of gambier powder filtrate concentration and mixed separation method on water vapour transmission rate (g.m ${ }^{-2}$.day ${ }^{-1}$ ) of edible film.

\begin{tabular}{crc}
\hline Treatment & \multicolumn{1}{c}{ Average } & HSD $5 \%=0.30$ \\
\hline $\mathrm{A}_{1} \mathrm{~B}_{1}$ & $20.23+0.131$ & $\mathrm{a}$ \\
$\mathrm{A}_{2} \mathrm{~B}_{1}$ & $20.57+0.064$ & $\mathrm{~B}$ \\
$\mathrm{~A}_{3} \mathrm{~B}_{1}$ & $20.88+0.063$ & $\mathrm{c}$ \\
$\mathrm{A}_{1} \mathrm{~B}_{3}$ & $21.15+0.094$ & $\mathrm{c}$ \\
$\mathrm{A}_{2} \mathrm{~B}_{3}$ & $21.4675+0.036$ & $\mathrm{~d}$ \\
$\mathrm{~A}_{3} \mathrm{~B}_{3}$ & $21.6142+0.182$ & $\mathrm{de}$ \\
$\mathrm{A}_{1} \mathrm{~B}_{2}$ & $21.7610+0.062$ & $\mathrm{de}$ \\
$\mathrm{A}_{2} \mathrm{~B}_{2}$ & $21.9077+0.158$ & $\mathrm{e}$ \\
$\mathrm{A}_{3} \mathrm{~B}_{2}$ & $22.2431+0.036$ & $\mathrm{f}$ \\
\hline
\end{tabular}

Remarks: Numbers followed by the same letters at the same columns are not significantly different $(\alpha=0.05)$.

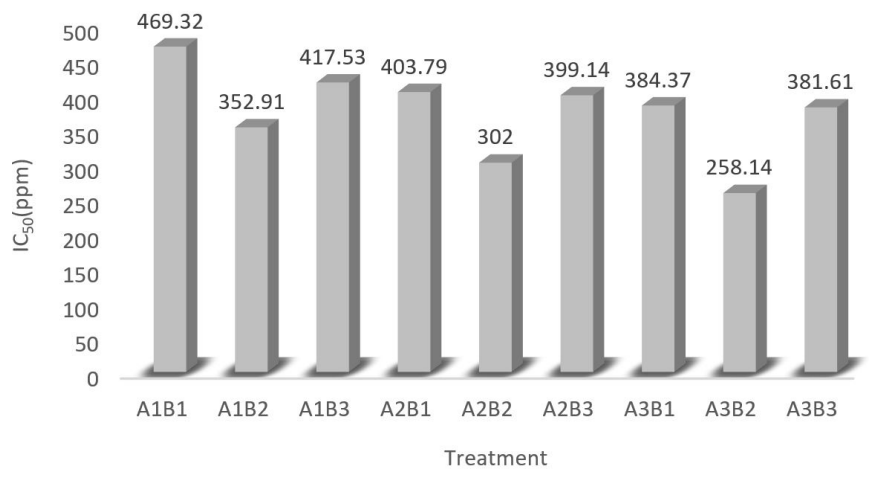

Figure 4. Average value of $\mathrm{IC}_{50}$ of edible film.

both treatments had no significant effect on $\mathrm{IC}_{50}$ of edible film. Results of HSD test for treatments of gambier powder filtrate concentration and mixed separation method toward $\mathrm{IC}_{50}$ value of edible film were shown in Table 1 and 2, respectively.

HSD test (Table 1) results showed that higher concentration of gambier powder filtrate in edible film matrix results in lower $\mathrm{IC}_{50}$ value, that is higher concentration of gambier powder filtrate results in higher antioxidant characteristic of edible film. This is due to the fact that catechins compound in gambier powder filtrate has antioxidant characteristic. Gambier extract contains catechins as the main component and catechins is a polyphenol compound that has potential as antioxidant and antibacteria 


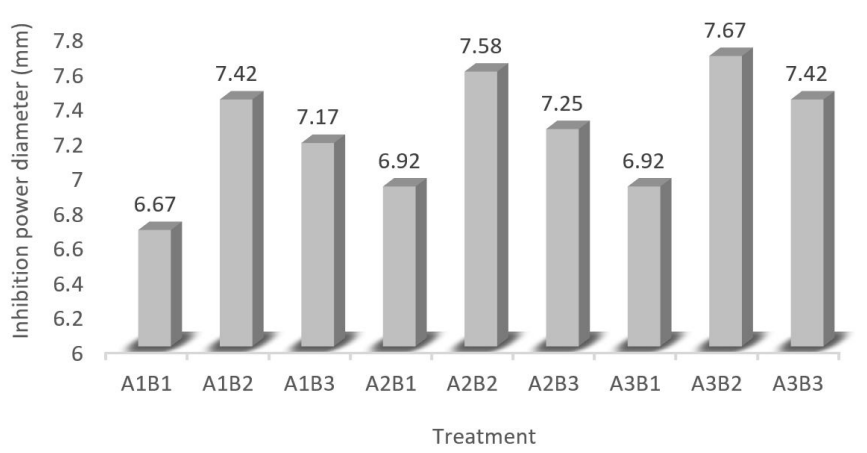

Figure 5. Average value of inhibition power diameter of edible film.

(Lucida et al., 2007). Pambayun (2007) had stated that gambeir powder extracted with water solvent at $30{ }^{\circ} \mathrm{C}$ produces $45 \%$ yield of extracts in phenolic contents and antibacterial properties.

Table 2 showed that mixed separation method by using $1000 \mathrm{rpm}$ centrifugation had higher antioxidant activity than that of other treatments. This is related to numbers of catechins compound available in gambier powder filtrate. Separation method by using $1000 \mathrm{rpm}$ centrifugation had higher catechin compound concentration within filtrate because soluble and insoluble components are followed by filtrate, whereas only soluble solid which enter into filtrate in case of separation method by using filter paper and centrifugation at $2000 \mathrm{rpm}$. These physical differences can be seen from filtrate color, that is filtrate produced from separation method by using $1000 \mathrm{rpm}$ centrifugation was clearer than that of two other treatments.

\subsection{Antibacterial activity}

Test of antibacterial activity was done by using disc method with Staphylococcus aureus as test bacteria. Average value of clear zone or inhibition power diameter (IPD) produced was in the range of 6.67 to $7.67 \mathrm{~mm}$. Average value of inhibition power diameter (IPD) was shown in Figure 5.

Analysis of variance results showed that treatments of gambier powder filtrate concentration and mixed separation method had significant effect on inhibition power diameter (IPD) of edible film, whereas interaction of both treatments had no significant effect on inhibition power diameter (IPD) of edible film. Results of HSD test for treatments of gambier powder filtrate concentration and mixed separation method toward inhibition power diameter (IPD) of edible film were shown in Table 1 and 2, respectively.

HSD test (Table 1) showed that higher concentration of gambier powder filtrate results in higher antibacterial activity of edible film. This is due to the fact that gambier filtrate contains catechins compound which pose antibacterial characteristic. According to Pambayun et al. (2012), catechins compound within commercial gambier product can inhibit Gram-positive bacteria through inhibition property as bactericidal.

Table 2 showed that treatment of mixed separation method at $1000 \mathrm{rpm}$ centrifugation had higher antibacterial characteristic than that of other treatments. This is in accordance to antioxidant characteristic of the produced edible film. The higher the antioxidant, the higher the antibacterial characteristic because catechins compound has antibacterial and antioxidant characteristics.

\section{Conclusion}

Corn starch-based edible film added with gambier filtrate has antibacterial and antioxidant characteristics. The best treatment based on physical, chemical and functional characteristics was $40 \%$ concentration of Uncaria gambir Roxb filtrate and the mixed separation method of $1000 \mathrm{rpm}$ centrifugation.

\section{Acknowledgements}

This research is part of the results of competitive excellent research which is funded by DIPA of Sriwijaya University Service Public Agency Budget of 2017 No.042.01.2.400953/2017 December 5, 2017 with Contract No.988/UN9.3.1/PP/2017 July 21, 2017.

\section{References}

American Society for Testing and Materials - ASTM. (1997). Annual book of ASTM standards. Philadelphia: ASTM.

Chaovanalikit, A., \& Wrolstad, R. E. (2004). Total anthocyanins and total phenolics of fresh and processed cheries and their antioxidant properties. JFS. Food Chemistry and Technology, 69(1), 67-72.

Hamilton-Miller, J. M. T., \& Shah, S. (2000). Activity of the tea component epicatechin gallate and analogue against methicillin-resistant Staphylococcus aureus. The Journal of Antimicrobial Chemotherapy, 46(5), 847-863. http://dx.doi.org/10.1093/jac/46.5.852.

Harmely, F., Deviarny, C., \& Yenni, W. S. (2014). Formulation and evaluation of edible film prepared from basil leaf (ocimum americanum 1.) As Mouth fresh. Journal of Pharmaceutical and Clinical Science, 1(1), 38-47.

Kusumawati, D. H., \& Putri, W. H. R. (2013). Physical and chemical characterisics of corn starch edible film incorporated with black Curcuma aeruginosa squeeze. Journal of Food and Agroindustry, 1(1), 90-100.

Ku K.-J., Hong Y.-H., \& Song, K. B. (2008). Mechanical properties of a Gelidium corneum edible film containing catechin and its application in sausages. Journal Food Science, 73(3), 217-222.

Lucida, H., Bakhtiar, A., \& Putri, W. A. (2007). Formulation preparation of mouth antiseptic from cathecin of gambier. Journal of Pharmaceutical Science and Technology, 12(1), 1-7.

Maizura, M., Fazilah, A., Norziah, M. H., \& Karim, A. A. (2007). Antibacterial activity and mechanical properties of partially hydrolyzed sago starch-alginate edible film containing lemongrass oil. Journal of Food Science, 72(6), 324-330. http://dx.doi.org/10.1111/j.17503841.2007.00427.x. PMid:17995673.

Molyneux, P. (2004). The use of the stable free radical diphenylpicrylhydrazyl (DPPH) for estimating antioxidant activity. Science Technology, 26(2), 211-219.

Nemet, N. T., Soso, V. M., \& Lazic, V. L. (2010). Effect of glycerol content and $\mathrm{pH}$ value of film-forming solution on the functional properties of protein-based edible films. Acta Periodica Technologica, 41(41), 57-67. http://dx.doi.org/10.2298/APT1041057N.

Pambayun, R., Gardjito, M., Sudarmadji, S., \& Kuswanto, K. R. (2012). Sensitivity of Gram positive bacteria toward cathecin extracted from gambier (Uncaria gambir Roxb). Agritech, 28(4), 174-179. 
Pambayun, R., Gardjito, M., Sudarmadji, S., \& Kuswanto, K. R. (2007). Phenol content and antibacterial properties from several types of gambier extract product (Uncaria gambir Roxb). Indonesia Pharmaceutical Magazine, 18(3), 141-146.

Park, D. P., Sung, J. H., Choi, H. J., \& Jhon, M. S. (2004). Electroresponsive characteristics of highly substituted phosphate starch. Journal of Materials Science, 39(19), 6083-6086. http://dx.doi.org/10.1023/ B:JMSC.0000041706.76102.b4.

Pranoto, Y., Salokhe, V. M., \& Rakshit, S. K. (2005). Physical and antibacterial properties of alginate-based edible film incorporated with garlic oil. Food Research International, 38(3), 267-272. http:// dx.doi.org/10.1016/j.foodres.2004.04.009.

Rodriguez, M., Oses, J., Ziani, K., \& Mate, J. I. (2006). Combined effect of plasticizers and surfactants on the physical properties of starch based edible films. Food Research International, 39(8), 840-846. http://dx.doi.org/10.1016/j.foodres.2006.04.002.
Santoso, B., Marsega, A., Priyanto, G., \& Pambayun, R. (2016). Improvement of physical, chemical and antibacterial properties of ganyong starch based edible film. Agritech, 36(4), 379-386.

Santoso, B. (2011). Integration of Modified Starch, Surfactans, Protein and Gambir Plant Extract in Edible Film Processing (Doctoral dissertation). Program in Agricultural Science, Postgraduate Program, Sriwijaya University, Palembang.

Sobral, P. J. A., Menegalli, F. C., Hubinger, M. D., \& Roques, M. A. (2001). Mechanical, water vapor barrier and thermal properties of gelatin based edible films. Food Hydrocolloids, 15(4-6), 423-432. http://dx.doi.org/10.1016/S0268-005X(01)00061-3.

Taniguchi, S., Kuroda, K., Doi, K., Inada, K., Yoshikado, N., Yoneda, Y., Tanabe, M., Shibata, T., Yoshida, T., Hatano, T., \& Zasshi, Y. (2007). Evaluation of gambir quality based on quantitative analysis of polyphenolic constituents. Journal of the Pharmaceutical Society of Japan, 127(8), 1291-1300. http://dx.doi.org/10.1248/yakushi.127.1291. PMid:17666883. 